\title{
Penile prosthesis implantation: A solution or a dilemma for the couple
} IMPLANTE DE PRÓTESE PENIANA: UMA SOLUÇÃO OU UM DILEMA PARA O CASAL

\author{
Théo Lerner ${ }^{1}$, José Maria Soares Júnior ${ }^{1}$, Ana lúcia Cavalcanti ${ }^{1}$, Elsa Pereyra Gay ${ }^{1}$, Ana Regina dos Santos ${ }^{2}$, José Cury $^{2}$, \\ Miguel Srougl ${ }^{2}$, Edmund C. Baracat ${ }^{1}$
}

${ }^{1}$ Division of Gynecology, Department of Obstetrics and Gynecology, Hospital das Clínicas da Faculdade de Medicina da Universidade de São Paulo (HC-FMUSP), São Paulo, SP, Brazil 2Division of Urology, HC-FMUSP, São Paulo, SP, Brazil

The physical, social and psychological changes resulting from aging have a significant impact on the sexuality of both men and women. ${ }^{1-5}$

Among men, erectile dysfunction (ED) is a common cause of impaired quality of life. In the last decades, an arsenal of alternatives has been developed to deal with this problem. Local drugs such as injectable or intraurethral prostaglandins, systemic agents such as phosphodiesterase inhibitors, and mechanical methods including vacuum constriction devices are among the possibilities of non-surgical intervention. For cases in which vascularization or penile innervation is compromised, surgical treatment of ED is indicated involving placement of a penile implant. ${ }^{5}$ The two types of implants available are semi-rigid and inflatable, differing in cost and functional outcome.

As for women, climacteric corresponds to a period of transition marked by estrogen decline (hypoestrogenism). It is characterized by physical, metabolic and psychological changes with negative repercussions in the psychosocial domain and in sexuality. ${ }^{1-4}$ Culturally, society has stigmatized menopausal women in relation to their sex life. However, with the advent of hormone therapy and career advancement of many women, this perception has changed and sexual interest at this stage of life has once again been accepted. ${ }^{1-4}$ In addition to the urological assessment of the male partner, evaluating the physical changes that occur during perimenopause and which affect the sexuality of women is justified.

The influence of cultural and social factors related to the aging process and the expression of sexuality increases the complexity of treating couples with indication for a penile implant. Assessing the female partner's expectations and degree of satisfaction is critical.

The literature of the 1980s and 1990s dealt with female sexual satisfaction in a generic way and reported satisfaction experienced by most women in relation with their partner's prostheses. ${ }^{6,7}$ Some authors began to ques- tion the influence of cultural and social factors that prevented this satisfaction from being generalized. ${ }^{8}$ Beliefs related to erection, as an expression of desire (and therefore of love) and fear of infidelity, have generated prejudice against artificially induced erections by a significant proportion of women. ${ }^{9}$ Ultimately, another category of problems began to be observed: women with sexual dysfunctions prior to the treatment of erectile dysfunction, who had become accustomed to the problem of their husbands, began to experience high levels of stress as a result of the new demands and expectations associated with penile implant placement. ${ }^{10,11}$

Often, the couple's sexual interest disappears completely, being replaced by feelings of friendship and companionship after long years of marital life. The female partner is not always ready to resume sexual activities, which can pose a dilemma for the couple and even break the marital bond.

The prior sexual history of both partners needs to be investigated, including beliefs, fantasies, fears, and expectations related to the procedure. Doubts should be clarified, while conflicts in the relationship can be identified and properly managed. ${ }^{12}$

Couples therapy can be a useful tool for dealing with psychological and behavioral factors that hinder the marital bond and consequently sexual satisfaction. ${ }^{1-4}$ Thorough evaluation and sexuality counseling are fundamental for the prevention of negative impacts of a penile implant on the couple's relationship.

\section{References}

1. Galhardo CL, Soares JM Jr, Simões RS, Haidar MA, Rodrigues de Lima G, Baracat EC. Estrogen effects on the vaginal $\mathrm{pH}$, flora and cytology in late postmenopause after a long period without hormone therapy. Clin Exp Obstet Gynecol. 2006; 33(2):85-9.

2. Favarato MECS, Aldrighi JM. A mulher coronariopata no climatério após a menopausa: implicações na qualidade de vida. Rev Assoc Med Bras. 2001; 47(4):339-45. 
3. Souza MA, Fonseca AM, Bagnoli VR, Barros N, Neves EM, Moraes SDTA, et al. The expression of the estrogen receptor in obese patients with high breast density (HBD). Gynecol Endocrinol. 2014; 30(1):78-80.

4. Fleury HJ, Abdo CHN. Terapia de casal para superar disfunções sexuais. Diagn Tratamento. 2016; 21(1):45-8.

5. Gittens P, Moskovic DJ, Avila D Jr, Chandrashekar A, Khera M, Lipshultz LI. Favorable female sexual function is associated with patient satisfaction after inflatable penile prosthesis implantation. J Sex Med. 2011; 8(7):1996-2001.

6. McLaren RH, Barrett DM. Patient and partner satisfaction with the AMS 700 penile prosthesis. J. Urol. 1992; 147(1):62-5.

7. Gerstenberger DL, Osborne D, Furlow WL. Inflatable penile prosthesis: follow-up study of patient-partner satisfaction. Urology. 1979; 14(6):583-7.

8. Salama N. Satisfaction with the malleable penile prosthesis among couples from the Middle East: is it different from that reported elsewhere? Int J Impot Res. 2004; 16(2):175-80
9. Montorsi F, Guazzoni G, Bergamaschi F, Rigatti P. Patient-partner satisfaction with semirigid penile prostheses for Peyronie's disease: a 5-year followup study. J Urol. 1993; 150(6):1819-21.

10. Vakalopoulos I, Kampantais S, Ioannidis S, Laskaridis L, Dimopoulos P, Toutziaris C, et al. High patient satisfaction after inflatable penile prostheses implantation correlates with female partner satisfaction. J Sex Med. 2013 10(11):2774-81

11. Hartzell R, King SA, Goldstein I. "Partner Prosthesis Panic": management of female sexual dysfunction in partners of men undergoing penile prosthesis implantation. J Sex Med. 2016; 13:S239-62.

12. Pisano F, Falcone M, Abbona A, Oderda M, Soria F, Peraldo F, et al. The importance of psychosexual counselling in the re-establishment of organic and erotic functions after penile prosthesis implantation. Int J Impot Res. 2015; 27(5):197-200. 